Page 1 of $2 \quad \begin{aligned} & \text { Proj. } \\ & \text { ECN }\end{aligned}$

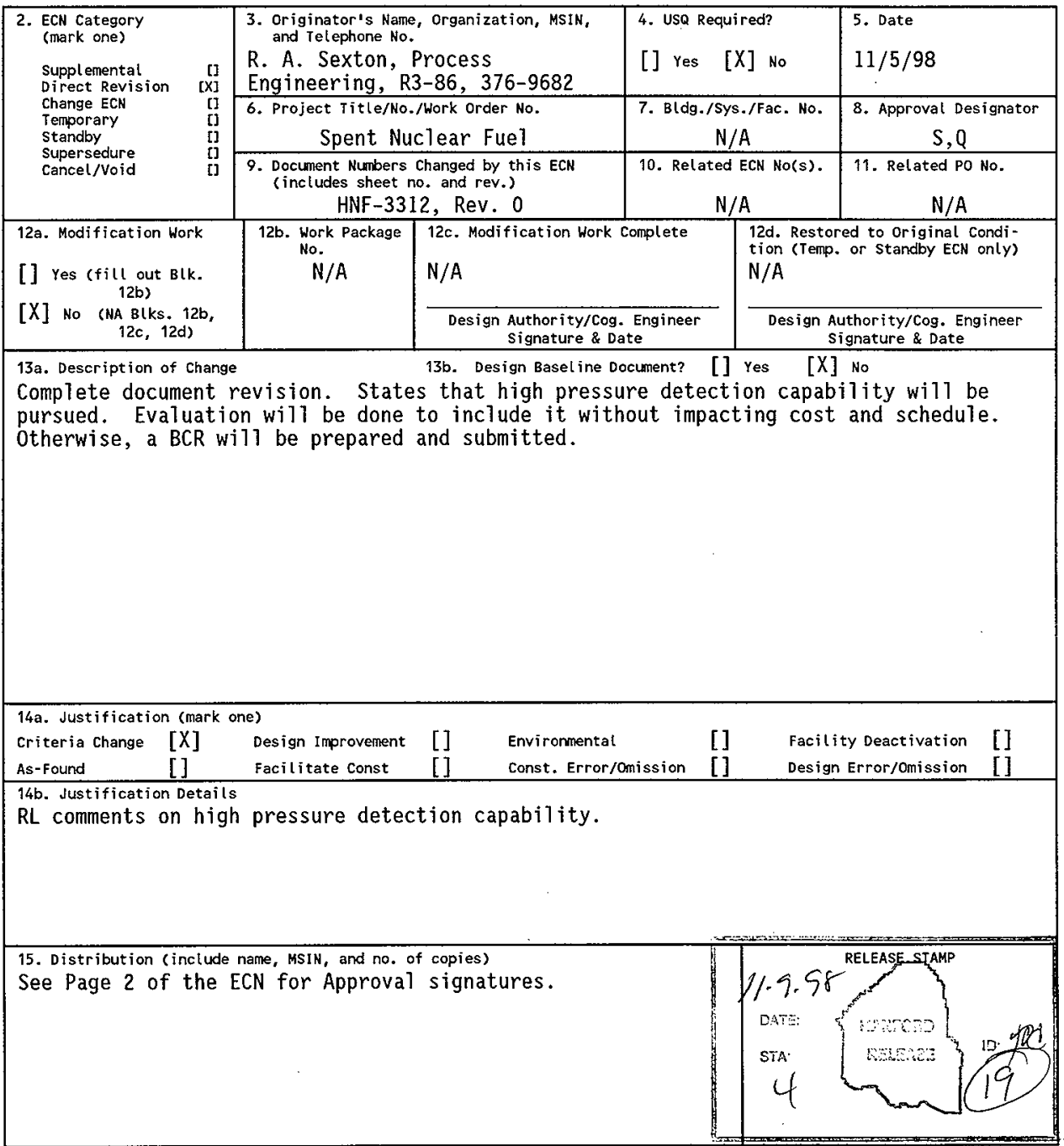

A-7900-013-2 (05/96) GEF095 


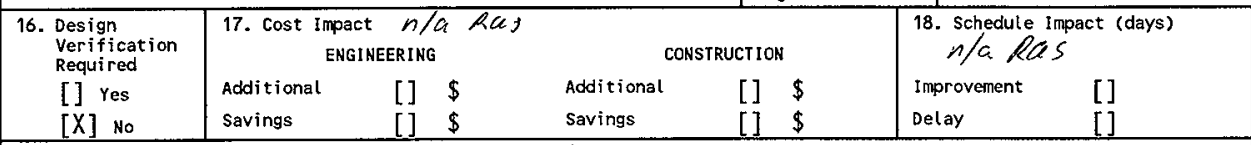

19. Change Impact Review: Indicate the related documents (other than the engineering documents ident ified on side 1 ) that will be affected by the change described in Block 13. Enter the affected document number in Block 20. SDD/DD

Funetional Design Criteria

Operating Specification

Criticality Specification

Conceptual Design Report

Equipment Spec.

Const. Spec.

Procurement Spec.

Vendor Information

OM Manual

FSAR/SAR

Safety Equipment List

Radiation Work Permit

Environmental Impact Statement

Environmental Report

Environmental Permit
[]
[]
[]
[]
[]
[]
[]
[]
[]
[]
[]
[]
[]
[]
[]
[]
Seismie/Stress Analysis

Stress/Design Report

Interface Control Drawing

Calibration Procedure

Installation Procedure

Maintenance Procedure

Engineering Procedure

Operating Instruction

Operating Procediure

Operational Safety Requirement

IEFD Drawing

Cell Arrangement Drawing

Essential Material Specification

Fac. Proc. Samp. Schedule

Inspection Plan

Inventory Adjustment Request
[]

[]

[]

[]

[]

[]

[]

[]

[]

[]

[]

[]

[]

[]

[]

[]
Tank Calibration Manual

Health Physics Proceduro

Spares Multiple Unit Listing

Test Procedures/Specification

Component Index

ASME Coded ltem

Human Factor Consideration

Computer Software

Electric Circuit Schedule

ICRS Procedure

Process Control Manual/Plan

Process Flow Chart

Purchase Requisition

Tickler File

20. Other Affected Documents: (NOTE: Documents tisted below will not be revised by this ECN.) Signatures below indicate that the signing organization has been notified of other affected documents listed below. Document Number/Revision

HNF-3354, Rev. 0

21. Approvals

Design Authority

signature

Cog. Eng.

Cog. Mgc. $P$ H. $R$ QA $P$ D. E: PAN

Safety R.P. Omberg

Environ.

other
Date

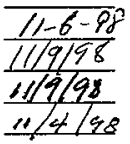

$11 / 4 / 98$

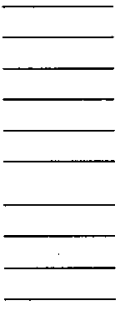

signature

Date
Design Agent

PE

QA

Safety

Design

Environ.

other

\section{DEPARTMENT OF ENERGY}

Signature or a Control Number that tracks the Approval Signature

\section{ADD I T IONAL}




\title{
MCO MONITORING ACTIVITY DESCRIPTION
}

\author{
*R. A. Sexton
}

DE\&S Hanford, Inc., Richland, WA 99352

U.S. Department of Energy Contract DE-AC06-96RL13200

$\begin{array}{lll}\text { EDT/ECN: } E C N-651401 & \text { UC: } 510 \\ \text { Org Code: } & 2 F 300 & \text { Charge Code: } 105355 \\ \text { B\&R Code: } & \text { RE3135040 } & \text { Total Pages: } 6\end{array}$

Key Words: Monitoring, CSB

Abstract: Spent Nuclear Fuel remaining from Hanford's N-Reactor operations in the 1970s has been stored under water in the K-Reactor Basins. This fuel will be repackaged, dried and stored in a new facility in the 200E Area. The safety basis for this process of retrieval, drying, and interim storage of the spent fuel has been established.

The monitoring of MCOs in dry storage is a currently identified issue in the SNF Project. This plan outlines the key elements of the proposed monitoring activity.

Other fuel stored in the K-Reactor Basins, including SPR fuel, will have other monitoring considerations and is not addressed by this activity description.

*Technical Resources International, Inc., Richland, WA.

IRADEMARK DISCLAIMER. Reference herein to any specific commercial product, process, or service by trade name, trademark, manufacturer, or otherwise, does not necessarily const itute or imply its endorsement, recomendation, or favoring by the United States Government or any agency thereof or its contractors or subcontractors.

Printed in the United States of America. To obtain copies of this document, contact: Document Control Services, P.O. Box 950, Mailstop H6-08, Richland WA 99352, Phone (509) 372-2420;

Fax (509) 376-4989.
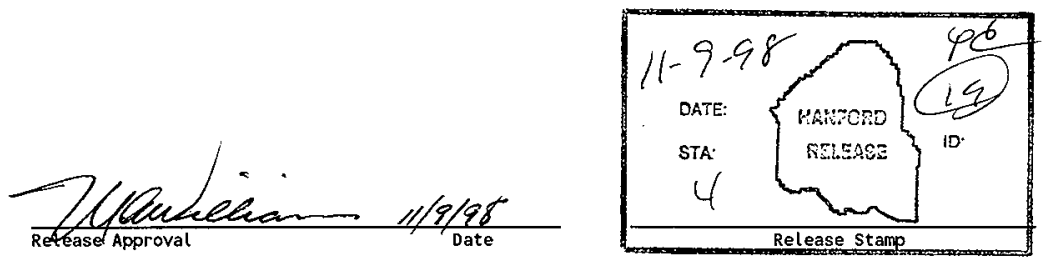

\section{Approved for Public Release}




\section{RECORD OF REVISION}

(1) Document Number

HNF-3312, Rev. I

Page 1

(2) Title

MCO MONITORING ACTIVITY DESCRIPTION

CHANGE CONTROL RECORD

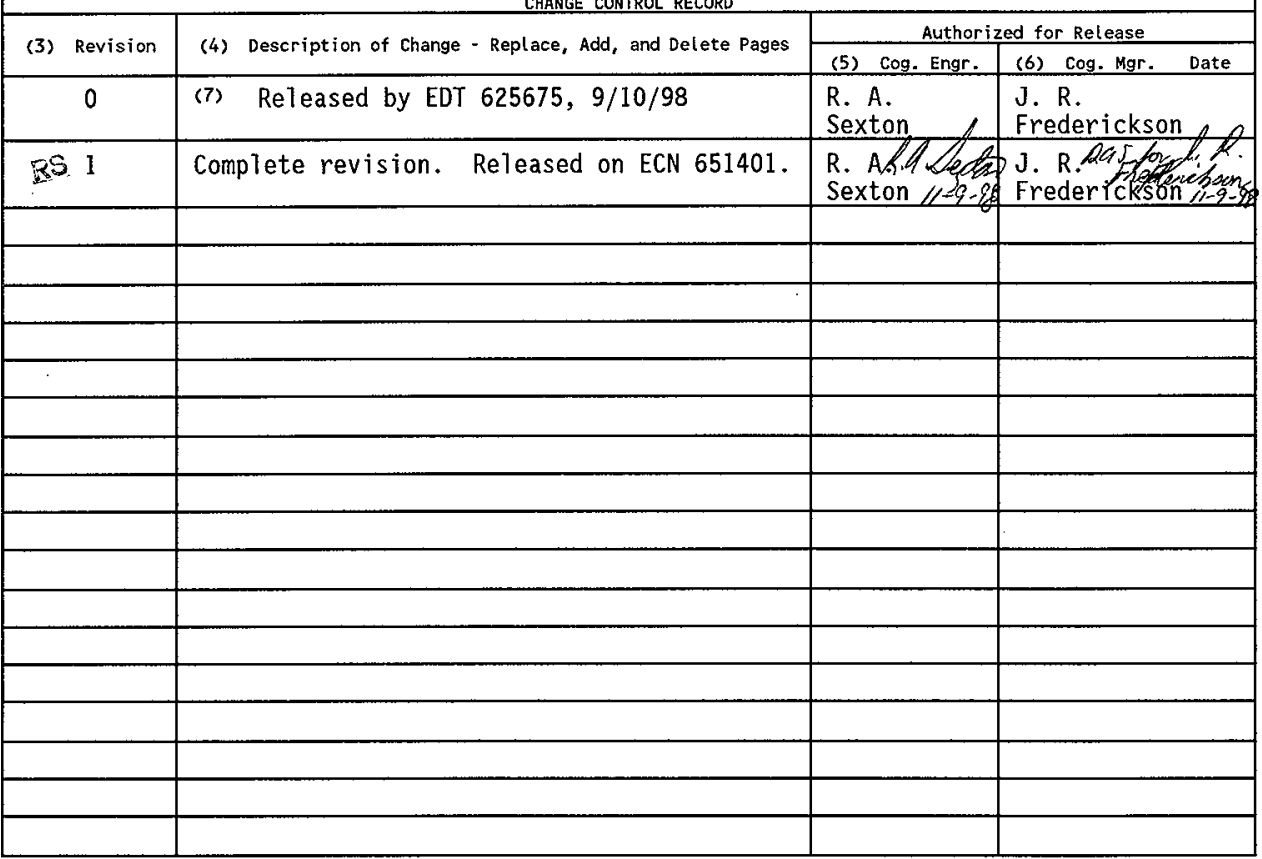


HNF-3312, Rev. 1

MCO MONITORING ACTIVITY DESCRIPTION

\section{TABLE OF CONTENTS}

1.0 INTRODUCTION $\quad . \quad$. $\quad . \quad$. $\quad . \quad$. $\quad . \quad$. 2

2.0 MONITORING OBJECTIVES. . . . . . . . . . 2

3.0 LIMITED OBSERVATION AND SAMPLING OF MCOS IN STORAGE $\quad \cdot \quad$. 3

4.0 MCO HIGH PRESSURE DETECTION CAPABILITY . . . . . . 4

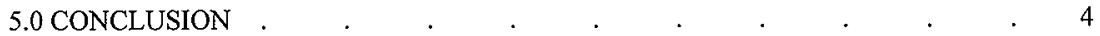


HNF-3312, Rev. 1

\section{MCO MONITORING ACTIVITY DESCRIPTION}

\subsection{INTRODUCTION}

Spent nuclear fuel remaining from Hanford's N Reactor operations in the 1970s has been stored under water in the $\mathrm{K}$ Reactor Basins. The $\mathrm{K}$ Basins are more than 40 years old and are less than a mile away from the Columbia River. This fuel will be retrieved and packed into containers (MCOs) each holding many fuel elements. The fuel in the MCOs will be dried and stored in a new facility, the Canister Storage Building, in the 200-E Area, away from the Columbia River. The safety basis for this process of retrieval, drying, and interim storage of the spent fuel has been established.

The monitoring of MCOs in dry storage is a currently identified issue in the SNF Project. This plan outlines key elements of the proposed monitoring activity.

Other fuel stored in the $\mathrm{K}$ Basins, including SPR fuel, will have other monitoring considerations and is not addressed by this activity description.

\subsection{MONITORING OBJECTIVES}

The safety of SNF Project processes for retrieving, packaging, handling, conditioning, and storing the $\mathrm{N}$ Reactor spent nuclear fuel has been demonstrated by conservative analyses, as compiled in the project safety basis and licensing documentation. Appropriate quality assurance and independent checking of engineering, fabrication, and construction are being applied, and there will be in-process monitoring and verification of MCO loading and conditioning actions. Once the MCOs have been placed in storage, there is no safety requirement, regulatory requirement, or precedent to monitor them.

Although not required, a limited monitoring program is considered valuable for several reasons:

Good engineering practice - Acquiring data at a reasonable cost that may be useful in developing a fuller understanding the behavior of an engineered system is good engineering practice.

Actual data on full scale MCOs is otherwise unavailable - Previous investigations have been limited to small fuel samples or simulant prototypes and have been relatively short in duration. MCO monitoring can provide data on large loads of actual fuel, in full scale configuration, over longer time periods. Additional knowledge of this fuel type may prove valuable in future analyses or applications.

On that basis, a limited program to observe pressure/temperature/gas composition relationships in a small number of MCOs during the first two years in storage, is planned. 
HNF-3312, Rev. 1

An additional monitoring consideration is the desirability of providing for simple future verification that internal MCO pressures are well within structural limits. The MCOs are likely to be stored for 40 years or longer. On that basis, it is desirable to incorporate in each $\mathrm{MCO}$ simple means to confirm at any time in the future, that internal pressure of the $\mathrm{MCO}$ is not high enough to threaten its structural integrity. While routine checking of such indication is not required or anticipated, the capability would always be available and is likely to be used prior to MCO handling and transport.

Monitoring is to be kept practical and cost effective such that it will not interfere with the fundamental project objective of putting the spent fuel in a safe configuration away from the river,

\subsection{LIMITED OBSERVATION AND SAMPLING OF MCOS IN STORAGE}

Objective: The MCO monitoring activity objective is to obtain data on the actual behavior of stored MCOs.

Scope: The MCO monitoring activity will permit acquisition of temperature, pressure, and gas composition data from a small number of MCOs over a limited period of time using nonintrusive, cost-effective data acquisition methods.

Impact to Project Baseline: Impacts must be minimized to CSB Operations staffing and throughput, and to the project cost and schedule baseline. No new activities may be introduced which would impact the Safety Analysis Report schedule.

Approach, in Concept: The proposed approach would monitor 4 to $6 \mathrm{MCO}$ for up to two years. Over the course of the MCO loading campaign, several MCOs would be designated for monitoring, based on the following target characteristics.

1) One MCO with minimal exposed fuel surface area and no aluminum hydroxide.

2) One MCO with minimal exposed fuel surface area, but high in aluminum hydroxide

3) One MCO from $K W$ high in exposed fuel surface area and scrap

4) One MCO from KE high in exposed fuel surface area and scrap

One or two additional MCOs could be included in the monitoring activity, if there are loadings of special interest identified during CVD operations, such as an MCO with two scrap baskets.

The designated MCOs would be staged and configured to permit monitoring, via engineered connections to ports in the mechanical closure head. Temperature and pressure will be recorded frequently or continuously. The pressure range of interest is 0 to $50 \mathrm{psig}$, with $2 \%$ accuracy. The temperature range of interest is 0 to $120^{\circ} \mathrm{C}$, with accuracy within $2^{\circ} \mathrm{C}$.

Gas sampling is proposed no more frequently than quarterly, with removal of a sample through a 
simple connection to the MCO.

Monitoring must be completed in time to weld the MCO closure and store the monitored MCO prior to SNF Project completion.

Monitoring Location: Location is under evaluation. It is anticipated that monitoring will be conducted with the MCOs in storage tube (upper positions) at locations selected based on accessibility and minimum interference with other MCO handling. A special monitoring station could also be established. For reasons of data quality and quantity, it is intended to conduct monitoring at a location that does not require frequent $\mathrm{MCO}$ movement.

Implementation Actions: Three steps are required to implement the monitoring described above.

1) Gain concurrence from the DOE-RL and the TAG on the proposed monitoring approach.

2) Perform up-front engineering, including detailed requirements, alternatives evaluation, conceptual design, and safety analysis/hazards analysis review. A DN may be required.

3) Enact monitoring, including the detailed design, fabrication, and implementation of the monitoring activity. A DN may be required.

\subsection{MCO HIGH PRESSURE DETECTION CAPABILITY}

Objective: Provide a means of confirming that the internal pressure of each MCO is well within its structural capability, anytime in its life.

Scope: Provide high pressure detection capability in each MCO, and provide means of accessing the detection, as desired.

Impact to Project Baseline: The detectors must not be developmental, but must have been demonstrated in a similar application. They must not require maintenance or routine inspection, must be unaffected by radiation, and must not diminish the MCO pressure capability.

Approach, in Concept: A specific approach has not yet been determined. Available technology is being evaluated to determine whether this detection can be included in the MCOs without impacting cost and schedule. Otherwise, a BCR will be prepared and submitted.

\subsection{CONCLUSION}

This properly focused, limited monitoring program should be implemented as part of the SNF Project. 


\section{DISTRIBUTION COVERSHEET}

Subject: MCO ISSUE PAPERS PER ATTACHED DISTRIBUTION INDEX

\section{DISTRIBUTION}

\begin{tabular}{|c|c|c|}
\hline Name & Location & w/att \\
\hline \multicolumn{3}{|l|}{ Spent Nuclear Fuel Project } \\
\hline W. C. Alaconis & R3-86 & $\mathrm{X}$ \\
\hline G. D. Bazinet & S8-06 & $\mathrm{X}$ \\
\hline J. D. Cloud & $\mathrm{R} 3-86$ & $\mathrm{X}$ \\
\hline D. R. Duncan & R3-86 & $\mathrm{X}$ \\
\hline J. R. Frederickson & R3-86 & $\mathrm{X}$ \\
\hline L. J. Garvin & $\mathrm{R} 3-26$ & $X$ \\
\hline L. H. Goldmann & $\mathrm{R} 3-86$ & $\mathrm{X}$ \\
\hline A. R. Hollins, Jr. & R3-86 & $\mathrm{X}$ \\
\hline C. R. Hoover & R3-86 & $\mathrm{X}$ \\
\hline J. J. Irwin & $\mathrm{R} 3-86$ & $\mathrm{X}$ \\
\hline B. D. Lorenz & $\mathrm{R} 3-26$ & $\mathrm{X}$ \\
\hline C. R. Miska & $\mathrm{R} 3-86$ & $\mathrm{X}$ \\
\hline R. G. Morgan & $\mathrm{R} 3-26$ & $\dot{X}$ \\
\hline R. P. Omberg & $\mathrm{H} 0-40$ & $\mathrm{X}$ \\
\hline A. M. Segrest & R3-11 & $X$ \\
\hline R. A. Sexton & R3-86 & $X$ \\
\hline K. E. Smith & $\mathrm{R} 3-86$ & $X$ \\
\hline J. A. Swenson & $\mathrm{R} 3-11$ & $\mathrm{X}$ \\
\hline N. H. Williams & $\mathrm{R} 3-11$ & $\mathrm{X}$ \\
\hline Project File & R3-11 & $x$ \\
\hline U.S. Department of Energy & . & \\
\hline C. B. Loftis & S7-41 & $X$ \\
\hline P. G. Loscoe & S7-41 & $X$ \\
\hline E. D. Sellers & $\mathrm{S} 7-41$ & $\mathrm{X}$ \\
\hline J. B. Sullivan & S7-41 & $\mathrm{X}$ \\
\hline
\end{tabular}




\section{DISTRIBUTION INDEX}

The Multi-Canister Overpack Issue papers listed below are being distributed as a package to facilitate future reference and use by SNF Project personnel. The following issue papers are attached:

1. HNF-2876, Oxygen Gettering Issue Closure Package

2. HNF-3265, MCO Number of Shield Plug Ports

3. HNF-3399, MCO Necessity of the Rupture Disk

4. HNF-3267, MCO Dual Pressure Rating

5. HNF-3293, MCO Ultrasonic Examination of Closure Weld

6. HNF-3354, MCO Monitoring Issue Closure Package and HNF-3312, MCO Monitoring Activity Description

7. HNF-3292, MCO Sealing Configuration

8. HNF-3266, MCO Design Pressure Rating

9. HNF-3255, ASME Code Requirements for MCO Design and Fabrication

10. HNF-3398, MCO Inservice Inspection and Maintenance

11. HNF-3420, MCO Internal HEPA Filters

12. HNF-3036, Low Reactive Surface Area Issue Closure Package

13. HNF-3270, MCO Pressure Testing 